Article

\title{
Investigations of the Optical and Thermal Properties of the Pyrazoloquinoline Derivatives and Their Application for OLED Design
}

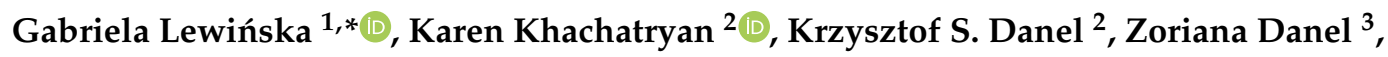 \\ Jerzy Sanetra $^{4,+}$ and Konstanty W. Marszałek ${ }^{1}$ (D) \\ 1 Department of Electronics, Faculty of Computer Science, Electronics and Telecommunications, \\ AGH University of Science and Technology; 30-059 Krakow, Poland; marszale@agh.edu.pl \\ 2 Department of Chemistry, Faculty of Food Technology, University of Agriculture in Krakow, \\ 30-149 Krakow, Poland; karen.khachatryan@urk.edu.pl (K.K.); rrdanelk@cyf-kr.edu.pl (K.S.D.) \\ 3 Institute of Physics, Faculty of Materials Science and Physics, Cracow University of Technology, \\ 30-035 Krakow, Poland; zusatenko@pk.edu.pl \\ 4 Institute of Physics, Faculty of Physics of Mathematics and Computer Science, \\ Cracow University of Technology, 30-841 Cracow, Poland; jsanetra@agh.edu.pl \\ * Correspondence: glewinska@agh.edu.pl; Tel.: +48-692-376-639 \\ + The author Jerzy Sanetra is retired.
}

Received: 19 October 2020; Accepted: 8 November 2020; Published: 16 November 2020

check for updates

\begin{abstract}
In this study, the photo-optical properties of the series of new 1H-pyrazolo[3,4-b]quinoline derivatives were investigated. Pyrazoloquinoline studies were conducted to explain the electroluminescent effect in organic LEDs. Absorption and photoluminescence spectra for the materials under consideration were examined, and quantum chemical calculations were made. Differential scanning calorimetric and thermogravimetric measurements were carried out for the manufactured materials. The phase situation of the materials was determined, and glassy transitions were detected for three of the investigated materials. Degradation temperatures were obtained. Single-layer luminescent diodes based on the ITO/PEDOT:PSS/active layer/Al scheme were fabricated. Current-voltage and brightness-voltage characteristics of the diodes were determined, ignition voltage was calculated, and electroluminescence types were determined.
\end{abstract}

Keywords: OLED; pyrazoloquinoline; differential scanning calorimetry; thermogravimetry

\section{Introduction}

Since the experiments of Tang et al. [1,2] on light emission from organic materials proved to be successful, research concerning optoelectronics has achieved a new impetus, and even today the rate of discovery of new materials is not slowing. Organic light-emitting diodes (OLEDs) [3-5], a type of light-emitting diode, are produced from organic compounds. OLEDs [6-8], as a surface light source [9,10], are commonly used to build flexible displays [11-13], TV sets [14,15], memory devices [16,17], solar cells [18-21], or other portable devices [22-24]. These materials have several advantages: they can be easily modified [25], they are cheaper to produce than inorganic materials, and they are also more energy efficient [26-29].

Quinoline derivatives are well-known materials for optoelectronic applications [30-32]. Organic compounds that are used for this purpose must be characterized by a good efficiency of converting electricity into light, and the required spectra of electroluminescence $[33,34]$. In addition, these materials can be easily processed under the influence of temperature, electric charge flow, and light. 
Quinoline is an organic compound with high electroluminescence efficiency [35] that is also easy to modify [36,37]. By modifying quinoline, it is possible not only to change the emission spectrum [38,39], but also other physical properties such as temperature sensitivity, resistance and photochemical changes or conductivity, and spatial properties [40-42]. A purposeful synthesis is important in order to obtain functional materials as a result $[43,44]$. The challenge is also to create a copolymer with a monomer which has better conduction properties and greater transmission of energy and electric charge [45].

Quinoline derivatives are well-known materials for optoelectronic applications [46], and can be modified relatively easily by changing the bases [47]. We present new derivatives of pyrazoloquinolines (PQs) and their optical properties, thermal tests [48,49], and manufactured devices in this paper.

\section{Materials and Methods}

Many modern pharmaceuticals, agrochemicals, and other advanced materials contain at least one fluorine atom, which usually has a specific function [50]. Because of this, fluorine is also used in the presented materials as one of the substituents. All materials were purchased from Sigma-Aldrich (Poznań, Poland).

Equimolar amounts of aniline, aldehyde, and pyrazolone were heated to reflux in ethylene glycol for several hours. After cooling, methanol was added, and the mixture was heated to reflux for $30 \mathrm{~min}$ (Figure 1). Afterwards, yellow powders were collected and recrystallized from the appropriate solvents to deliver pure compounds. All compounds presented in Table 1, with codes F1 to F7, were obtained in the same manner.
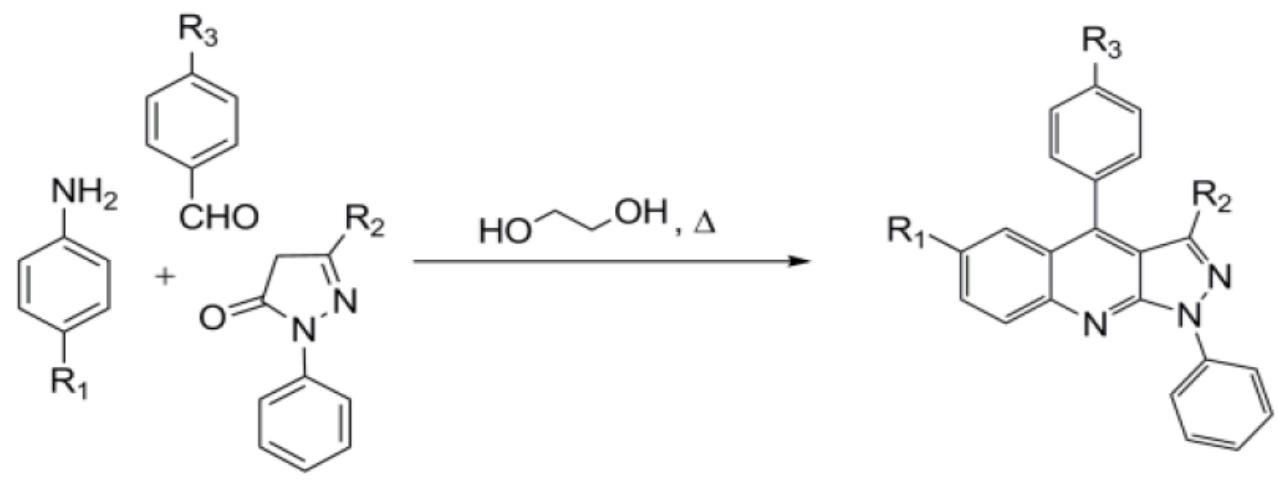

F1-F7

Figure 1. The one-pot procedure to prepare pyrazolo[3,4-b]quinolines F1-F7.

Table 1. Symbols and names of investigated compounds and substituents R1, R2, R3.

\begin{tabular}{|c|c|c|c|c|}
\hline Symbol & Compound Name & R1 & $\mathbf{R} 2$ & $\mathbf{R} 3$ \\
\hline F1 & $\begin{array}{l}\text { 4-(4-tert-butylphenyl)-6-fluoro-3-methyl- } \\
\text { 1-phenyl-1H-pyrazolo[3,4-b]quinoline }\end{array}$ & $\begin{array}{c}\mathrm{F} \\
\text { (fluorine) }\end{array}$ & $\begin{array}{c}t \text {-Bu } \\
(t-\text { butyl })\end{array}$ & $\begin{array}{c}\text { Me } \\
\text { (methyl) }\end{array}$ \\
\hline $\mathrm{F} 2$ & $\begin{array}{l}\text { 6-tert-butyl-4-(4-fluorophenyl)-3-methyl- } \\
\text { 1-phenyl-1H-pyrazolo[3,4-b]quinoline }\end{array}$ & $\begin{array}{c}t \text {-Bu } \\
(t \text {-butyl) }\end{array}$ & $\begin{array}{c}\mathrm{F} \\
\text { (fluorine) }\end{array}$ & $\begin{array}{c}\text { Me } \\
\text { (methyl) }\end{array}$ \\
\hline F3 & $\begin{array}{l}\text { 6-ethyl-4-(4-fluorophenyl)-3-methyl- } \\
\text { 1-phenyl-1H-pyrazolo[3,4-b]quinoline }\end{array}$ & $\begin{array}{c}\text { Et- } \\
\text { (ethylene) }\end{array}$ & $\begin{array}{c}\mathrm{F} \\
\text { (fluorine) }\end{array}$ & $\begin{array}{c}\text { Me } \\
\text { (methyl) }\end{array}$ \\
\hline $\mathrm{F} 4$ & $\begin{array}{l}\text { 4-(4-fluorophenyl)-3,6-dimethyl- } \\
\text { 1-phenyl-1H-pyrazolo[3,4-b]quinoline }\end{array}$ & $\begin{array}{c}\mathrm{Me} \\
\text { (methyl-CH3) }\end{array}$ & $\begin{array}{c}\mathrm{F} \\
\text { (fluorine) }\end{array}$ & $\begin{array}{c}\text { Me } \\
\text { (methyl) }\end{array}$ \\
\hline F5 & $\begin{array}{l}\text { 4-(4-fluorophenyl)-6-methoxy-3-methyl- } \\
\text { 1-phenyl-1H-pyrazolo[3,4-b]quinoline }\end{array}$ & $\begin{array}{c}\text { OMe } \\
\text { (O-methyl) }\end{array}$ & $\begin{array}{c}\mathrm{F} \\
\text { (fluorine) }\end{array}$ & $\begin{array}{c}\text { Me } \\
\text { (methyl) }\end{array}$ \\
\hline F6 & $\begin{array}{l}\text { 4-(4-chlorophenyl)-6-fluoro-3-methyl- } \\
\text { 1-phenyl-1H-pyrazolo[3,4-b]quinoline }\end{array}$ & $\begin{array}{c}\mathrm{F} \\
\text { (fluorine) }\end{array}$ & $\begin{array}{c}\mathrm{Cl} \\
\text { (chlorine) }\end{array}$ & $\begin{array}{c}\text { Me } \\
\text { (methyl) }\end{array}$ \\
\hline F7 & $\begin{array}{l}\text { 4-(4-fluorophenyl)-3-isopropyl-6-methoxy- } \\
\text { 1-phenyl-1H-pyrazolo[3,4-b]quinoline }\end{array}$ & $\begin{array}{c}\text { OMe } \\
\text { (O-methyl) }\end{array}$ & $\begin{array}{c}\mathrm{F} \\
\text { (fluorine) }\end{array}$ & $\begin{array}{c}i-\operatorname{Pr} \\
\text { (isopropyl) }\end{array}$ \\
\hline
\end{tabular}




\section{Results}

\subsection{Quantum Chemical Calculations}

The optimized ground-state geometries of compounds F1-F7 were estimated using the DFT model, employing hybrid functional Becke3-Lee-Yang-Parr (B3LYP) with a basis set B3LYP/6-31G(d,p) and B3LYP/6-31+G(d,p), to calculate the highest occupied molecular orbital (HOMO) and the lowest unoccupied molecular orbital (LUMO) values [51]. The differences in energy levels give a value of $0.3 \mathrm{eV}$, as calculated by both methods (see Table 2). The electron-donating moieties at the C-6 of the PQ skeleton raise the HOMO levels whenever the electron-withdrawing moieties decrease them. Similar trends are observed in LUMO energy levels. The calculations performed at B3LYP/6-31G(d) in chloroform give results lower by a factor of $\sim 0.15 \mathrm{eV}$, regardless of HOMO/LUMO levels. In the following, we compare the measured optical absorption spectra with the excitation spectra, evaluated by the DFT/TDDFT (density-functional theory/time-dependent density-functional theory) method at the B3LYP/6-31G(d) level of theory.

Table 2. Energy HOMO and LUMO levels calculated by TDDFT method by different levels of theory for investigated compounds F1-F7.

\begin{tabular}{cccccccc}
\hline \multicolumn{2}{c}{ Level of Theory } & \multicolumn{2}{c}{ B3LYP/6-31G(d,p) } & \multicolumn{2}{c}{ B3LYP/6-31+G(d,p) } & \multicolumn{2}{c}{ B3LYP/6-31G(d) } \\
\hline Compound symbol & $\begin{array}{c}\mathrm{R} 1 \\
\mathrm{~F}\end{array}$ & HOMO & LUMO & HOMO & LUMO & HOMO & LUMO \\
F1 & $\begin{array}{c}\text { fluorine) } \\
t-\text { Bu }\end{array}$ & 5.42 & 1.96 & 5.73 & 2.28 & 5.57 & 2.05 \\
F2 & $\begin{array}{c}t \text {-butyl) } \\
\text { Et } \\
(\text { ethylene) } \\
\text { Me }\end{array}$ & 5.39 & 1.86 & 5.68 & 2.16 & 5.54 & 1.94 \\
F3 & 5.39 & 1.88 & 5.69 & 2.19 & 5.54 & 1.95 \\
F4 & $\begin{array}{c}\text { (methyl) } \\
\text { OMe }\end{array}$ & 5.31 & 1.85 & 5.61 & 2.17 & 5.44 & 1.94 \\
F5 & $\begin{array}{c}\text { o-methyl) } \\
\text { F } \\
\text { (fluorine) }\end{array}$ & 5.56 & 2.14 & 5.86 & 2.45 & 5.63 & 2.14 \\
F6 & $\begin{array}{c}\text { OMe } \\
\text { (o-methyl) }\end{array}$ & 5.32 & 1.84 & 5.62 & 2.16 & 5.45 & 1.93 \\
\hline
\end{tabular}

The results of the TDDFT calculation of the highest maximum in $\lambda_{\max }$ superviolet in chloroform, and the oscillator strength (which is a measure of absorption intensity of new compounds) are presented in Table 3.

Table 3. Results of TDDFT calculations of $\lambda_{\max }$ in chloroform for the new compounds.

\begin{tabular}{ccc}
\hline Compound & $\lambda_{\max }(\mathbf{n m})$ & f. Oscillator Strength \\
\hline \multirow{2}{*}{ F1 } & 416.6 & 0.103 \\
& 274.6 & 1.198 \\
F2 & 405.8 & 3.055 \\
& 279.9 & 4.429 \\
F3 & 408.7 & 0.089 \\
& 279.9 & 0.756 \\
F4 & 406.7 & 0.094 \\
& 279.3 & 0.653 \\
F5 & 415.6 & 0.103 \\
& 277.9 & 0.994 \\
F6 & 420.3 & 0.091 \\
& 278.7 & 0.577 \\
F7 & 413.6 & 0.105 \\
& 276.9 & 1.016 \\
\hline
\end{tabular}


The results in Table 3 were obtained by inserting the optimized structure of the above into the TDDFT calculation method and calculating the wavelength $\left(\lambda_{\max }\right)$ of the maximum of the absorption spectrum for each compound placed in chloroform. Simulated data are similar to the experimental results presented in Table 4.

Table 4. Maxima of absorption and photoluminescence spectra of the investigated materials F1-F7 ( $\lambda_{\text {ex }}$-laser excitation wavelength).

\begin{tabular}{ccccc}
\hline Compounds & $\begin{array}{c}\text { Absorption Maxima } \\
\text { in Absorption Band } \\
\mathbf{2 4 0 - 3 4 0}(\mathbf{n m})\end{array}$ & $\begin{array}{c}\text { Absorption Maxima } \\
\text { in Absorption Band } \\
\mathbf{4 0 0 - 6 5 0}(\mathbf{n m})\end{array}$ & $\begin{array}{c}\text { Maximum of } \\
\text { Photoluminescence Spectra } \\
\left(\boldsymbol{\lambda}_{\mathbf{e x}}=\mathbf{4 0 5} \mathbf{n m}\right)(\mathbf{n m})\end{array}$ & Stokes Shift (nm) \\
\hline F1 & 275 & 400 & 490 & 90 \\
F2 & 275 & 402 & 472 & 70 \\
F3 & 275 & 410 & 472 & 60 \\
F4 & 280 & 410 & 470 & 70 \\
F5 & 282 & 410 & 480 & 80 \\
F6 & 280 & 410 & 490 & 65 \\
F7 & 282 & 410 & 475 & \\
\hline
\end{tabular}

\subsection{Optical Properties}

Absorption and photoluminescence spectra of all compounds were measured using the HR4000CGUVNIR spectrometer by Ocean Optics. The graphs are presented in Figures 2 and 3, respectively, and illustrate the quantitative dependence of absorbance versus wavelengths for the given organic materials.
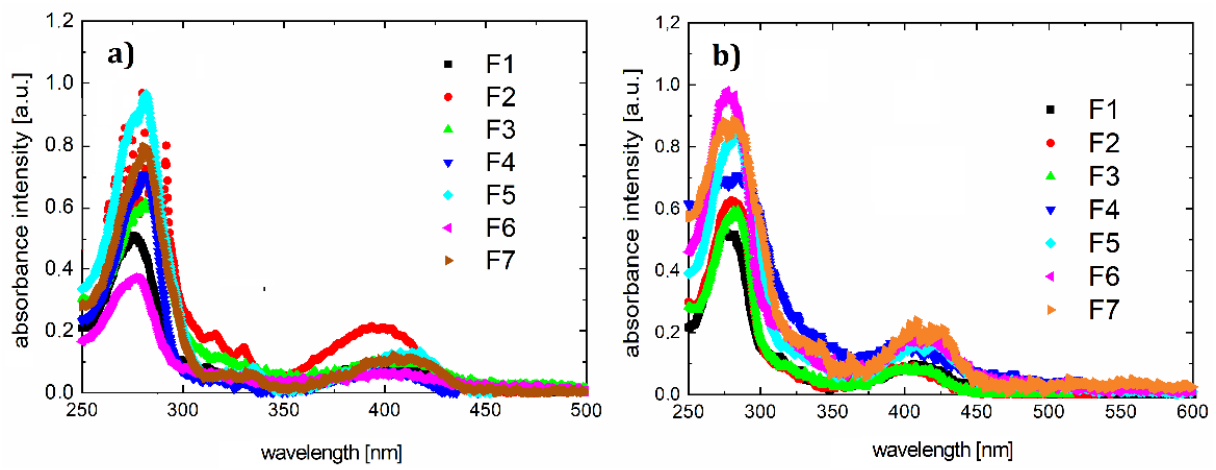

Figure 2. Absorption spectra for F1-F7 samples in chloroform (a) and thin film on quartz (b).
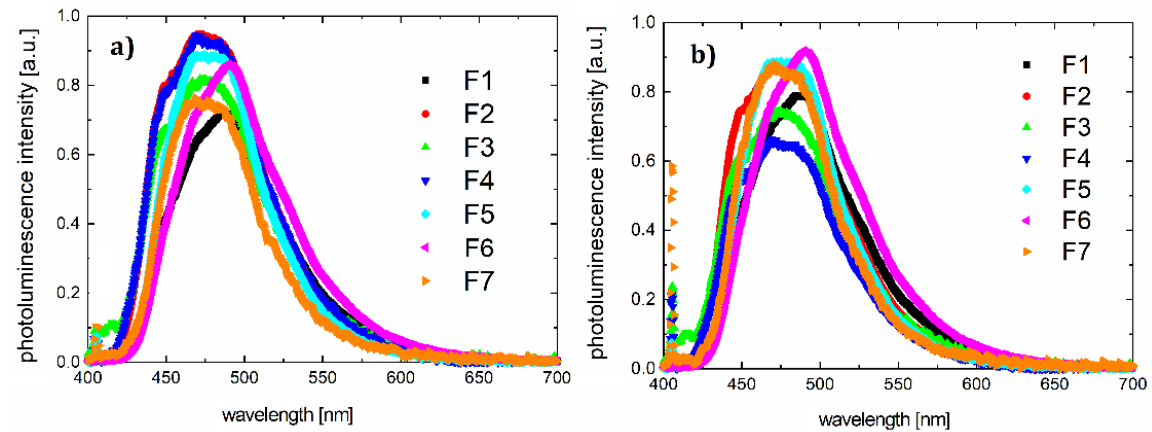

Figure 3. Photoluminescence spectra for samples F1-F7 in (a) chloroform and (b) thin film on quartz $\left(\lambda_{\mathrm{ex}}=405 \mathrm{~nm}\right)$.

The absorption of the pyrazoloquinoline derivatives was measured in a liquid state (solution in chloroform of spectroscopic grade that was purchased by Merck KGaA, Darmstadt, Germany), and in solid-state as a thin layer on quartz.

In the range of $250-650 \mathrm{~nm}$, the optical absorption spectra of dyes are quite similar. The stronger absorption band appears in the spectral range of $240-340 \mathrm{~nm}$, which can be associated with $\pi^{*}$ transition. 
The second absorption band is observed in the spectral range 415-650 $\mathrm{nm}$ and can be associated with transition $\mathrm{n}^{*}$. Maxima for individual bands and maximum photoluminescence are listed in Table 4.

Energy gaps obtained from theoretical calculations (presented in Table 2) are about $3.5 \mathrm{eV}$ for all compounds F1-F7. This is confirmed experimentally by the results of the absorption measurments and indicates that the absorption spectra are almost identical, although HOMO and LUMO energy levels are different. Other energy levels should affect the ignition voltage and possibly the intensity of the light.

Subtle differences in peaks are caused by differences in the molecules. This may also be demonstrated by discrepancies in the Stokes shift values (differing by approximately $25 \mathrm{~nm}$ ).

On the basis of the results presented, it can be concluded that the spectra of the individual compounds F1-F7 do not differ greatly (Figure 2a). In addition, the absorption spectrum in the solid state is slightly shifted towards long (about $10 \mathrm{~nm}$ ) wavelengths, compared to those made in chloroform solution.

Inserting substitutes does not affect the absorption spectrum significantly. The entire absorption is dominated by the skeleton of the molecule. The same luminescence spectrum behavior is observed. According to the absorption and photoluminescence spectra, Stokes shifts were determined as shown in Table 4. A sample chart for F3 is shown in Figure 4.

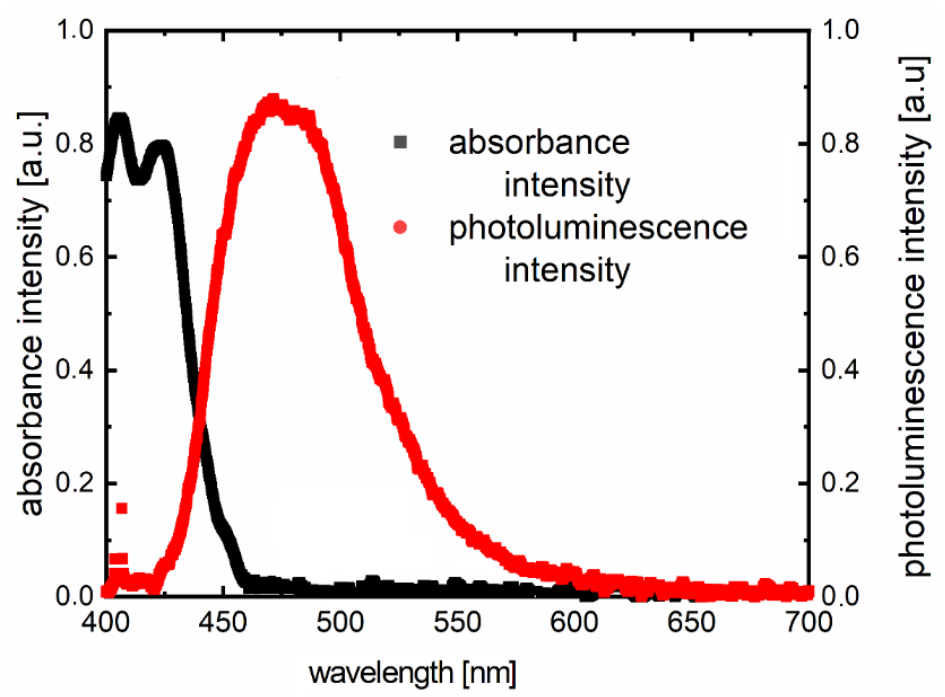

Figure 4. Example of the Stokes shift for sample F3 from Table 2. The photoluminescence has been excited by a diode laser $\left(\lambda_{\mathrm{ex}}=405 \mathrm{~nm}\right)$.

\subsection{Thermogravimetry (TG) and Differential Scanning Calorimetry (DSC) Study}

The thermogravimetric analysis (TGA), coupled with simultaneous differential thermal analysis (SDTA) and mass spectrometry evolved gas analysis (MS-EGA), was performed in a Mettler-Toledo 851e Thermo-Analyser Columbus, OH, USA) using $150 \mu \mathrm{L}$ corundum crucibles under a flow of argon $(80 \mathrm{~mL} / \mathrm{min})$, within the temperature range $30-600{ }^{\circ} \mathrm{C}$ with a heating rate of $5{ }^{\circ} \mathrm{C} / \mathrm{min}$. The simultaneous MS-EGA was performed in an online joined quadrupole mass spectrometer (QMS) (Thermostar-Balzers, Mettler-Toledo, Columbus, OH, USA).

Representative thermogravimetric curves of percent mass losses as a function of temperature for the investigated compounds are presented in Figure 5. The compounds have a similar degradation temperature for the materials shown in Table 5. 


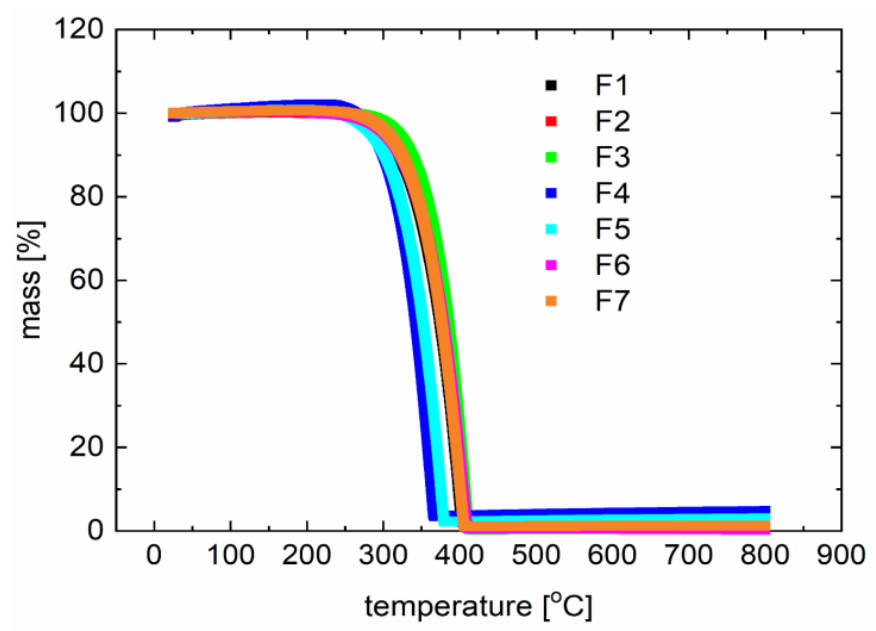

Figure 5. Typical thermogravimetric (TG) curves for derivatives F1 to F7 (described in Table 1).

Table 5. Parameters of the DSC curves.

\begin{tabular}{|c|c|c|c|c|c|}
\hline Compound & $\begin{array}{l}\text { Speed of the DSC } \\
\text { Process }\left({ }^{\circ} \mathrm{C} / \mathrm{min}\right)\end{array}$ & $\begin{array}{c}\text { DSC Heating Peak(s) } \\
\left({ }^{\circ} \mathrm{C}\right)\end{array}$ & $\begin{array}{c}\text { DSC Cooling Peak(s) } \\
\left({ }^{\circ} \mathrm{C}\right)\end{array}$ & $\begin{array}{c}\text { Capillary Method } \\
\text { m.p. }\left({ }^{\circ} \mathrm{C}\right)\end{array}$ & $\begin{array}{l}\mathrm{T}_{\mathrm{deg}} \\
\left({ }^{\circ} \mathrm{C}\right)\end{array}$ \\
\hline \multirow{2}{*}{ F1 } & 10 & 210 & 141,136 & \multirow{2}{*}{$218-221$} & \multirow[t]{2}{*}{340} \\
\hline & 15 & 214 & 156 & & \\
\hline \multirow{2}{*}{ F2 } & 12 & 187 & - & \multirow{2}{*}{ 192-193 } & \multirow{2}{*}{438} \\
\hline & 10 & 175,180 & - & & \\
\hline \multirow{2}{*}{ F3 } & 15 & 209,216 & 150 & \multirow{2}{*}{$161-162$} & \multirow{2}{*}{350} \\
\hline & 15 & 212 & 114 & & \\
\hline \multirow[b]{2}{*}{ F4 } & 15 & 248 & 332 & \multirow{2}{*}{$211-212$} & \multirow{2}{*}{306} \\
\hline & 10 & 240 & 330 & & \\
\hline \multirow{2}{*}{ F5 } & 10 & 166 & 104 & \multirow{2}{*}{$211-212$} & \multirow{2}{*}{317} \\
\hline & 12 & 170 & 111 & & \\
\hline \multirow{2}{*}{ F6 } & 10 & 213 & 168 & \multirow{2}{*}{185} & \multirow{2}{*}{344} \\
\hline & 15 & 207 & 161 & & \\
\hline \multirow{2}{*}{ F7 } & 10 & 192 & - & \multirow{2}{*}{$247-249$} & \multirow{2}{*}{341} \\
\hline & 12 & 199 & - & & \\
\hline
\end{tabular}

The degradation temperature is above $300^{\circ} \mathrm{C}$, which also confirms the broad application potential. The temperatures observed with the capillary method slightly deviate from those observed with differential scanning calorimetry measurements.

Calorimetric measurements were performed using a Mettler-Toledo 821e calorimeter equipped with a Haake intracooler under an argon flow $(80 \mathrm{~mL} / \mathrm{min})$ within a temperature range of $25-600{ }^{\circ} \mathrm{C}$. The measurements were done in $40 \mu \mathrm{L}$ aluminum crucibles closed by a lid with a hole ( $1 \mathrm{~mm}$ diameter) and $5-10 \mathrm{mg}$ of sample. The heating and cooling curves are shown in Figure 6.
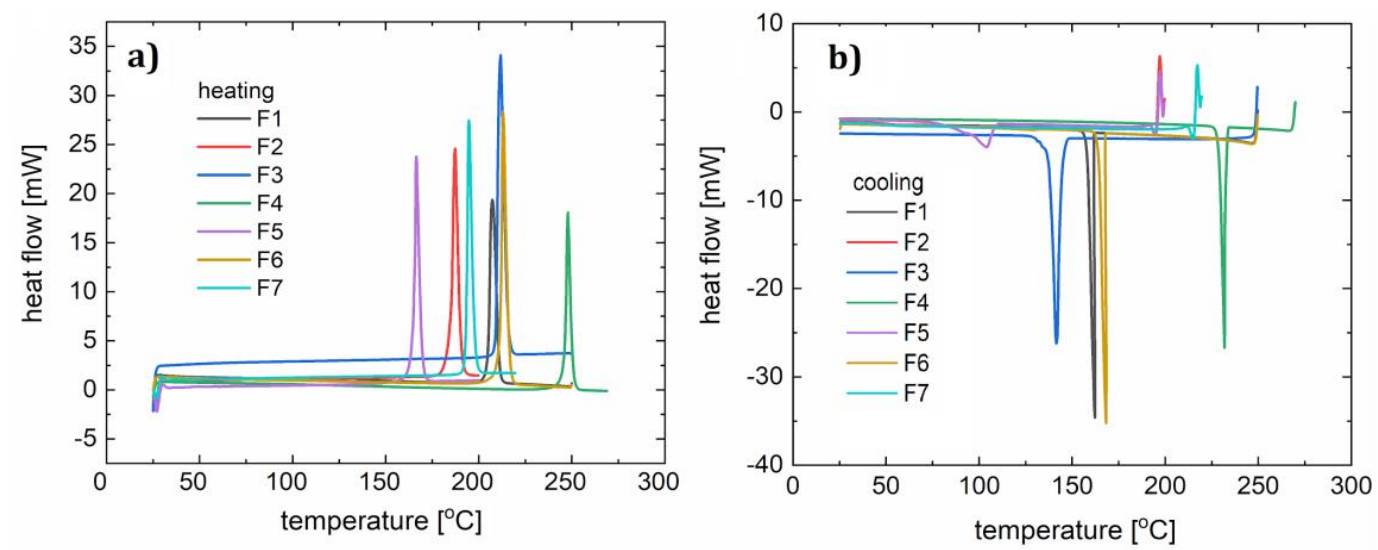

Figure 6. DSC curves for samples F1-F7: heating (a) and cooling (b). 
The melting range of all the synthesized compounds spans from $160^{\circ} \mathrm{C}$ to nearly $210{ }^{\circ} \mathrm{C}$ (Table 5) in $p$-fluorophenyl series $\mathrm{R}_{1}=\mathrm{Et}, t-\mathrm{Bu}, \mathrm{Me}$, and $\mathrm{OMe}$ (F2-F5 and F7). The biggest contribution to increasing the melting point was the isopropyl moiety $\mathrm{R}_{3}=i$-Pr. Exchanging the positions of a fluorine atom and $t$-butyl is also advantageous in enhancing thermal properties. Similar trends were previously observed, and those derivatives are highly crystalline compounds that decompose at around $400{ }^{\circ} \mathrm{C}$.

Two heating and cooling cycles were carried out for each material (Figure 7). For the polymer F1, during the first heating cycle $\left(10^{\circ} \mathrm{C} / \mathrm{min}\right)$ the melting process (with a corresponding peak maximum at $210^{\circ} \mathrm{C}$ ) and a two-stage crystallization (peaks at $141^{\circ} \mathrm{C}, 138^{\circ} \mathrm{C}$ ) occurred. Two peaks observed on the curve indicate an additional state of order of the molecules. In the second cycle $\left(15^{\circ} \mathrm{C} / \mathrm{min}\right)$ the melting process (peak at $214^{\circ} \mathrm{C}$ ) and a crystallization (peak at $156^{\circ} \mathrm{C}$ ) were noted. For compound $\mathrm{F} 2$ in the first cycle $\left(12{ }^{\circ} \mathrm{C} / \mathrm{min}\right)$, a clear melting point was observed at $187^{\circ} \mathrm{C}$, followed by the creation of a glassy phase later during the process. During heating in the second cycle $\left(10^{\circ} \mathrm{C} / \mathrm{min}\right)$, a softening glass transition at $62{ }^{\circ} \mathrm{C}$ was observed, followed by an endothermic process with a maximum of $123^{\circ} \mathrm{C}$ (associated with the spontaneous crystallization of the cooled liquid) and double melting (at $175^{\circ} \mathrm{C}$ and $180^{\circ} \mathrm{C}$ ). The lower temperature transition is responsible for the transition from the solid phase to another solid phase with more molecular disorder. In both the first and second cooling cycles $\left(15^{\circ} \mathrm{C} / \mathrm{min}\right.$ ), a one-phase transition (at $150{ }^{\circ} \mathrm{C}$ and $114{ }^{\circ} \mathrm{C}$ ) can be distinguished on the DSC curve of compound F3. During heating in the first cycle, we observed two phase transitions (peak maxima at $209^{\circ} \mathrm{C}$ and $\left.216^{\circ} \mathrm{C}\right)$, and in the second cycle the DSC curve shows one maximum $\left(212^{\circ} \mathrm{C}\right)$. In this case, we also assume the creation of an additional metastate between the solid and liquid phases. For sample $\mathrm{F} 4$, both heating and cooling processes $\left(10^{\circ} \mathrm{C} / \mathrm{min}\right.$ and $\left.15^{\circ} \mathrm{C} / \mathrm{min}\right)$ show one phase transition during heating (peak at $248{ }^{\circ} \mathrm{C}$ in the first cycle, and at $240^{\circ} \mathrm{C}$ in the second cycle) and cooling (at $232{ }^{\circ} \mathrm{C}$ in the first cycle, and $230^{\circ} \mathrm{C}$ in the second cycle).

The first heating cycle $\left(10^{\circ} \mathrm{C} / \mathrm{min}\right)$ for compound F5 showed melting at $166^{\circ} \mathrm{C}$. During the cooling, a wide peak $\left(104^{\circ} \mathrm{C}\right)$ was observed. The second cycle $\left(12{ }^{\circ} \mathrm{C} / \mathrm{min}\right)$ showed glassy phase transitions (glass-liquid transition) with the maximum at $42^{\circ} \mathrm{C}$, and a following endothermic reaction at $91^{\circ} \mathrm{C}$, and melting at $170{ }^{\circ} \mathrm{C}$. Since the glassy transition appeared, it can be concluded that this phase transition (corresponding with a peak at $104^{\circ} \mathrm{C}$ ) was not a complete crystallization with ordering of the molecules. During the second cooling we observed one wide peak with a minimum at $111^{\circ} \mathrm{C}$.

F6 in both heating and cooling cycles showed one phase transition for each condition (for heating 213 and $207^{\circ} \mathrm{C}$, and for cooling 168 and $161^{\circ} \mathrm{C}$ ). This behavior is similar to that of F4. For F7, a melting point at $192^{\circ} \mathrm{C}$ was observed during heating. The second heating, like the first one, showed a glass transition at $61^{\circ} \mathrm{C}$, an endothermic process with the minimum at $61^{\circ} \mathrm{C}$ and a melting point at $199^{\circ} \mathrm{C}$. The phase condition of F7 is therefore analogous to that of F2 and F5, according to the fact that small molecules are susceptible to spontaneous crystallization during OLED operation. Glassy transitions, as well as all the morphological changes in the operating temperature range of diodes, are undesirable and so it can be concluded that these compounds are not suitable for optoelectronic applications. Therefore, glass transitions exclude compounds F2, F3, and F5 from being used as single layers in OLED devices. However, doping into an appropriate host material was considered. 

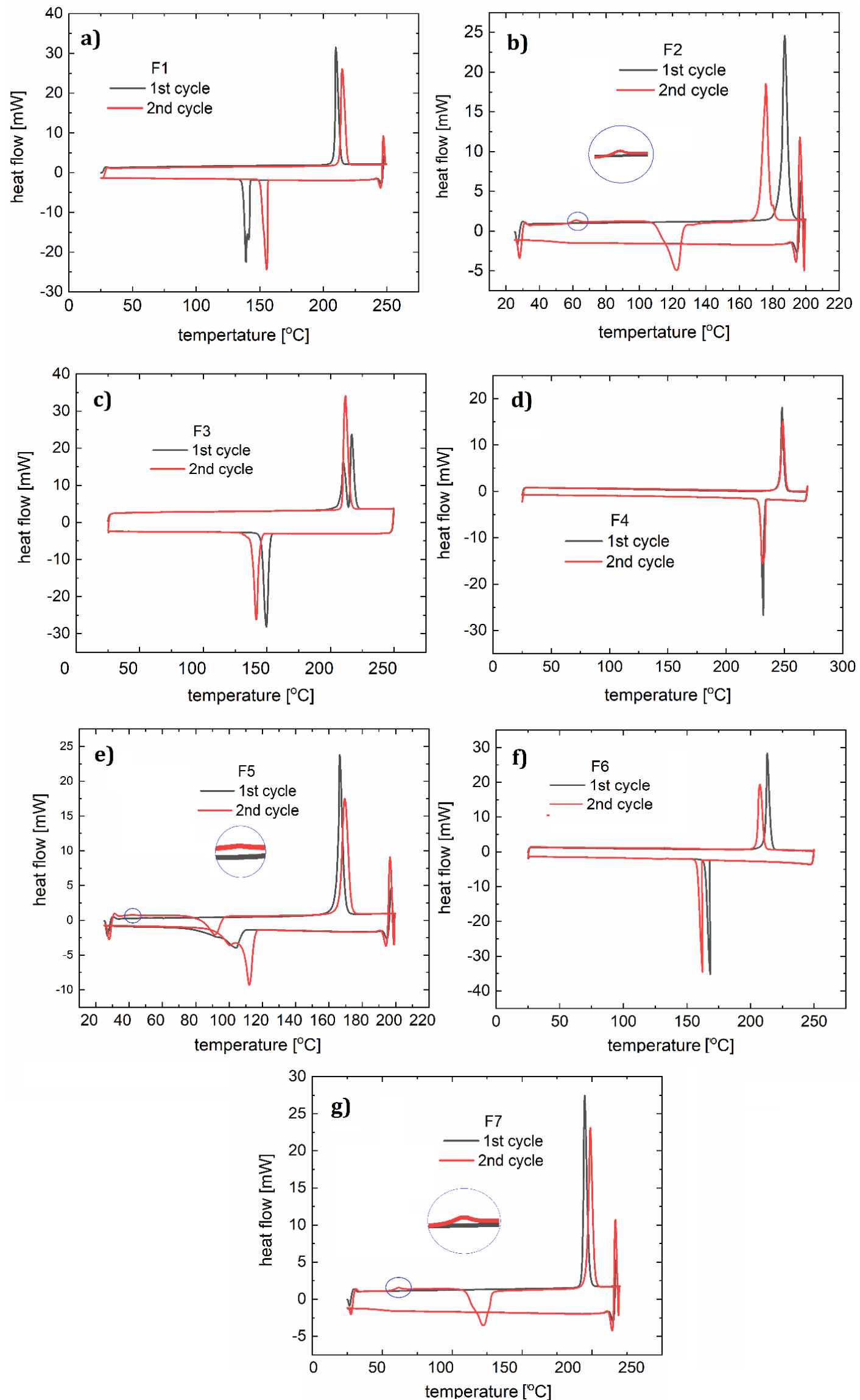

Figure 7. DSC curves with two heating and cooling cycles for: F1 (a), F2 (b), F3 (c), F4 (d), F5 (e), F6 (f), and F7 (g). 


\subsection{OLEDS}

After the photophysical properties were demonstrated, single-layer electroluminescent diodes were made. The diodes were built based on the ITO/active layer/Al scheme, with indium tin oxide [52] as a transparent electrode (provided by Merck KGaA, Darmstadt, Germany) and evaporation aluminum as a second electrode.

The active layer in this simple, sandwich-like architecture was poly( $N$-vinylcarbazole) (PVK) matrix and dyes (the ratio of dye:PVK was about 1:100).

The light emission mechanism of an organic material involves the injection of a charge from the electrode to the material. For light-emitting devices based on organic compounds, we are almost exclusively concerned with recombination electroluminescence. Based on the kinetic equations describing the charge carrier population, we consider the injection-controlled and volume-controlled electroluminescence models [53].

For ITO/PVK+F/Al diodes (shown in Figure 8a), designated as D1-D7, we obtained the currentvoltage (Figure $8 \mathrm{~b}$ ) and brightness-voltage characteristics (Figure $9 \mathrm{~b}$ ). The lowest ignition voltage was for diodes D5 and D6 (6.2 and 6.4 V, respectively). A value of the ignition voltage of about $7 \mathrm{~V}$ was shown by devices D7, D1, and D4. OLEDs D2 and D3 showed an ignition voltage of about $8 \mathrm{~V}$.

a)

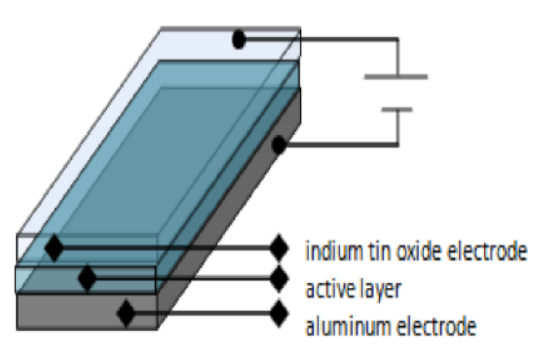

b)

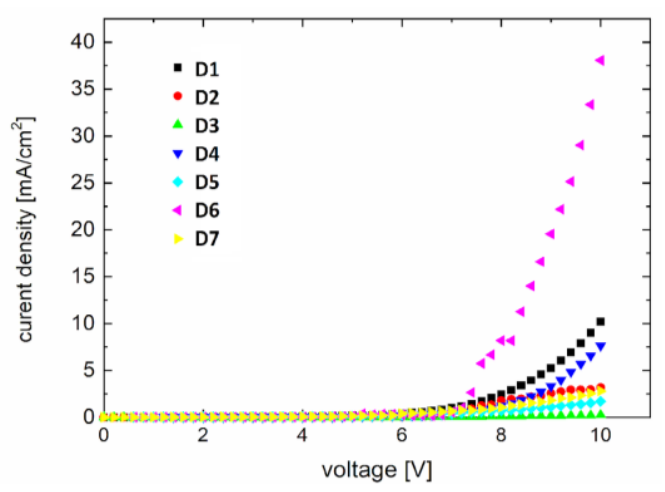

Figure 8. Device architecture (a) and current-voltage characteristics of diodes D1-D7 (b).
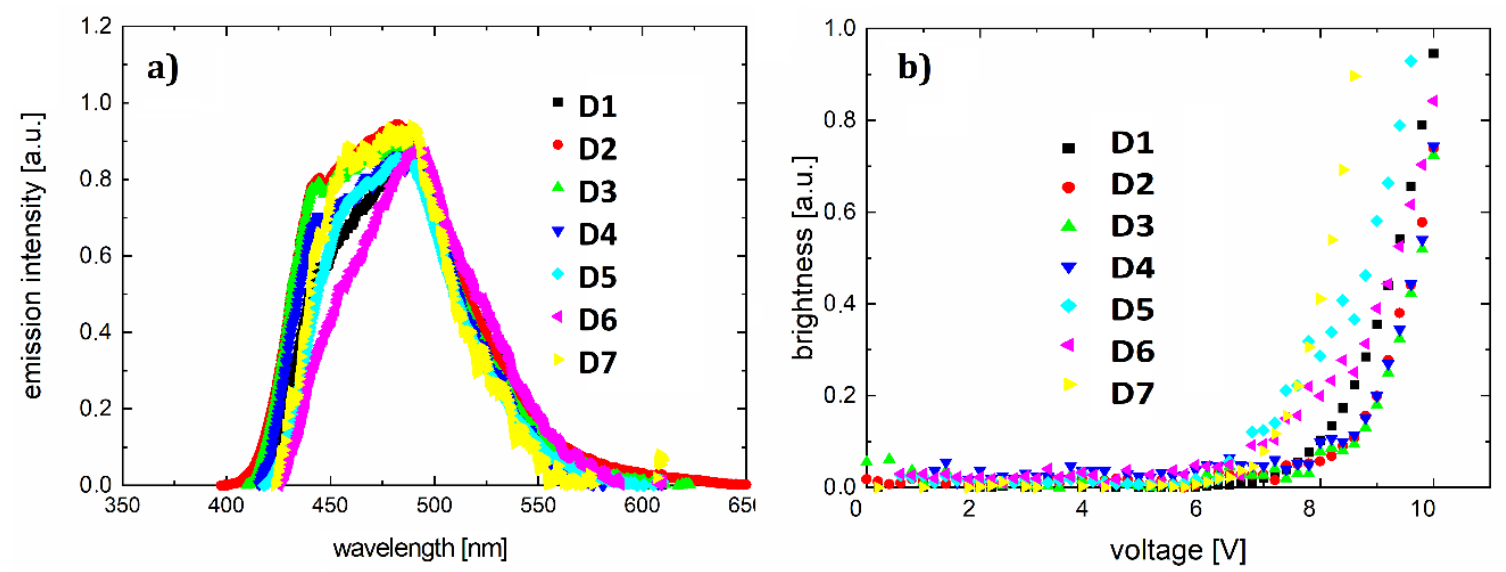

Figure 9. Electroluminescence spectra for D1-D7 (a) and brightness-voltage characteristics for diodes D1-D7 (b).

The resulting light-emitting spectra (Figure 9a) show a spectrum range from 425 to $570 \mathrm{~nm}$, with full width at half maximum of about $100 \mathrm{~nm}$. The electroluminescence maximum ranges from $481 \mathrm{~nm}$ (greenish-blue color) to $493 \mathrm{~nm}$ (bluish-green color). The parameters of the diodes are collected in Table 6. 
Table 6. Electroluminescent parameters of the organic diodes D1-D7.

\begin{tabular}{ccccc}
\hline $\begin{array}{c}\text { Organic Electroluminescent } \\
\text { Diode }\end{array}$ & $\begin{array}{c}\text { Diode Active Layer } \\
\text { Dye + PVK Matrix }\end{array}$ & $\begin{array}{c}\text { Wavelength of } \\
\text { Electroluminescence } \\
\text { Maximum (nm) }\end{array}$ & Ignition Voltage (V) & $\begin{array}{c}\text { Current-Electroluminescence } \\
\text { Exponent } \\
\boldsymbol{n}\end{array}$ \\
\hline D1 & F1 + PVK & 487 & 7.3 & 1.8 \\
D2 & F2 + PVK & 482 & 7.9 & 4.2 \\
D3 & F3 + PVK & 481 & 8.1 & 3.4 \\
D4 & F4 + PVK & 483 & 6.3 & 1.2 \\
D5 & F5 + PVK & 482 & 6.2 & 0.8 \\
D6 & F6 + PVK & 493 & 7.1 & 1.2 \\
D7 & F7 + PVK & 487 & & 2.4 \\
\hline
\end{tabular}

\section{Discussion}

The electroluminescence flux model for injecting charge carriers from electrodes into the active layer of a case of thermal injection, above the barrier of the potential in the presence of a field, is defined by Equation (1):

$$
\Phi_{e l} \propto\left(j^{e}, j^{h}\right)^{n}
$$

where $j^{h}$ and $j^{e}$ are hole and electron current density, and $n$ is the current-electroluminescence coefficient. Depending on the complexity of the model, the flux can be described with more parameters.

To determine the character of electroluminescence, the electroluminescence-current characteristics were presented on a double logarithmic scale for the investigated diodes (Figure 10). The linear function was adjusted to the characteristics. Based on the slope of the adjusted linear function, the current- electroluminescence exponent was determined. This allowed conclusions to be drawn about the electroluminescence model as well as the mechanism of charge-carrier injection.
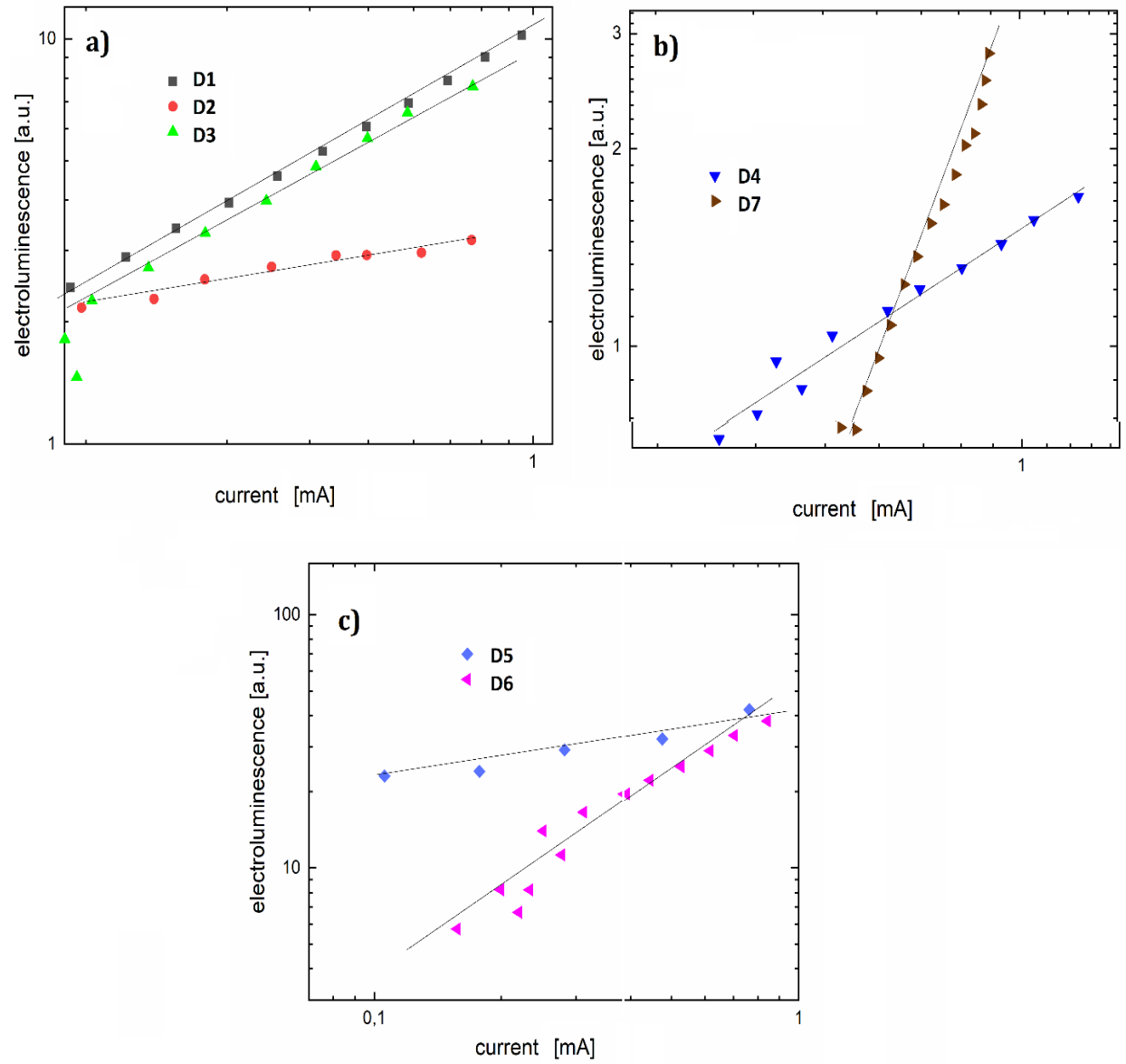

Figure 10. Log-log electroluminescence-current characteristics for organic light-emitting diodes (OLEDs) (a) D1, D2 and D3, (b) D4 and D7, (c) D5 and D6. 
Diode D1 with a coefficient $n=1.8$ showed a reduction in the potential barrier for holes, comparable to the electron potential barrier. The value of the exponent for diode D5 is close to unity, which is characteristic of the volumetric electroluminescent model. However, it can also indicate strong electron scattering. For diodes D4 and D6, the slope factor $n$ of 1.2 could be the result of electron trapping. Other devices have the following exponents: D2 $=4.2, \mathrm{D} 3=3.4$, and D7 $=2.4$. Analyzing the performance of individual luminescence devices can lead to the conclusion that the substituents do not affect the electroluminescence maximum. However, they definitely affect the ignition voltage and the mechanisms of electroluminescence.

To improve the device parameters, extra layers supporting the transport of holes or electrons are often used [54]. Diodes with an additional layer of poly(3,4-ethylenedioxythiophene)-poly(styrenesulfonate) (PEDOT:PSS) were pre-tested. Diodes of ITO/PEDOT:PSS/active layer/Al architecture were made and tested. Unfortunately, the ignition voltage increased, which is not favorable for diodes. The presented architecture (ITO/active layer/Al) is the best that was achieved.

\section{Conclusions}

This paper presents the synthesis of pyrazoloquinoline derivatives. HOMO and LUMO levels, as well as theoretical values of maximum absorption, were determined using quantum chemical simulations for the obtained compounds. The calculated results are in agreement with the experimental results.

The absorption and photoluminescence spectra were obtained and their maxima were determined. Electroluminescent investigation of pyrazoloquinoline derivatives demonstrated similar spectral features for all of the investigated compounds. Thermal measurements were also performed. Degradation temperatures in the investigated materials are high (above $300{ }^{\circ} \mathrm{C}$ ). Additionally, the capillary method was used to indicate high melting temperatures. However, DSC tests showed that three out of seven (D2, D5, and D7) compounds exhibit glass transitions. Organic electroluminescent diodes were also made using the tested compounds as a dye in the PVK matrix. The fabricated diodes show various mechanisms of electroluminescence. They light up in blue-greenish colors. Taking into consideration thermal properties and ignition voltages, the best materials for application are: (4-chlorophenyl)-6-fluoro-3-methyl-1-phenyl-1H-pyrazolo[3,4-b]quinoline (F6) and 4-(4-tert-butylphenyl)-6-fluoro-3-methyl-1-phenyl-1H-pyrazolo[3,4-b]quinoline (F1). We arranged diodes according to the increasing ignition voltage (D5, D6, D7, and D1). As the best of the diodes, those with the lowest ignition voltage were chosen. Unfortunately, diodes D5 and D7 have glassy transitions in the temperature range required for applications, and are thus eliminated from application possibilities. Therefore, the most optimal diodes are D6 and D1.

Author Contributions: Conceptualization, G.L., K.W.M.; software, Z.D.; investigation, G.L., K.K., K.S.D., J.S.; writing—original draft preparation, G.L.; writing—review and editing, G.L., K.W.M.; visualization, G.L.; supervision, K.W.M. All authors have read and agreed to the published version of the manuscript.

Funding: This research was funded by statutory project of Department of Electronics AGH University in Cracow. This research received no external funding.

Conflicts of Interest: The authors declare no conflict of interest.

\section{References}

1. Tang, C.W.; Vanslyke, S.A. Organic electroluminescent diodes. Appl. Phys. Lett. 1987, 51, 913-915. [CrossRef]

2. Tang, C.W.; Vanslyke, S.A.; Chen, C.H. Electroluminescence of doped organic thin films. J. Appl. Phys. 1989, 65, 3610-3616. [CrossRef]

3. Grabka, D.; Danel, A.; Kolbus, A.; Szary, K. Photophysical properties of 6-N,N-dimethylpyrazolo[3,4-b]quinoline substituted with pyridyl in the 3-position. Opt. Mater. 2017, 66, 527-533. [CrossRef]

4. Slodek, A.; Zych, D.; Maroń, A.; Golba, S.; Schab-Balcerzak, E.; Janeczek, H.; Siwy, M.; Maćkowski, S. Fluorene vs. carbazole substituent at quinoline core toward organic electronics. Dye. Pigment. 2019, 166, 98-106. [CrossRef] 
5. Thejo Kalyani, N.; Dhoble, S.J. Novel materials for fabrication and encapsulation of OLEDs. Renew. Sustain. Energy Rev. 2015, 44, 319-347. [CrossRef]

6. Bizzarri, C.; Spuling, E.; Knoll, D.M.; Volz, D.; Bräse, S. Sustainable metal complexes for organic light-emitting diodes (OLEDs). Coord. Chem. Rev. 2018, 373, 49-82. [CrossRef]

7. Ledwon, P. Recent advances of donor-acceptor type carbazole-based molecules for light emitting applications. Org. Electron. 2019, 75, 105422. [CrossRef]

8. Wang, S.; Zhang, H.; Zhang, B.; Xie, Z.; Wong, W.Y. Towards high-power-efficiency solution-processed OLEDs: Material and device perspectives. Mater. Sci. Eng. R Rep. 2020, 140, 100547. [CrossRef]

9. Mahesh, K.; Karpagam, S.; Goubard, F. Conductive and photoactive nature of conjugated polymer based on thiophene functionalized thiazole or benzothiadiazole. Express Polym. Lett. 2018, 12, 238-255. [CrossRef]

10. Li, J.; Qiao, B.; Zhao, S.; Song, D.; Zhang, C.; Xu, Z. Investigation on OLEDs efficiency roll-off with interfacial charge storage and their time-resolved emission spectra. Org. Electron. 2020, 83, 105756. [CrossRef]

11. Steudel, S.; Myny, K.; Schols, S.; Vicca, P.; Smout, S.; Tripathi, A.; Van Der Putten, B.; Van Der Steen, J.L.; Van Neer, M.; Schütze, F.; et al. Design and realization of a flexible QQVGA AMOLED display with organic TFTs. Org. Electron. 2012, 13, 1729-1735. [CrossRef]

12. Jia, Y.; Liu, Z.; Wu, D.; Chen, J.; Meng, H. Mechanical simulation of foldable AMOLED panel with a module structure. Org. Electron. 2019, 65, 185-192. [CrossRef]

13. Tokito, S. High-Performance Organic Thin-Film Transistors for Flexible AM-OLED Displays. In ECS Transactions; The Electrochemical Society: Pennington, NJ, USA, 2008; Volume 16, pp. 23-31.

14. Tsai, T.C.; Hung, W.Y.; Chi, L.C.; Wong, K.T.; Hsieh, C.C.; Chou, P.T. A new ambipolar blue emitter for NTSC standard blue organic light-emitting device. Org. Electron. 2009, 10, 158-162. [CrossRef]

15. Yin, M.; Pan, T.; Yu, Z.; Peng, X.; Zhang, X.; Xie, W.; Liu, S.; Zhang, L. Color-stable WRGB emission from blue OLEDs with quantum dots-based patterned down-conversion layer. Org. Electron. 2018, 62, 407-411. [CrossRef]

16. Liu, H.; Bala, H.; Zhang, B.; Zong, B.; Huang, L.; Fu, W.; Sun, G.; Cao, J.; Zhan, Z. Thickness-dependent photovoltaic performance of $\mathrm{TiO} 2$ blocking layer for perovskite solar cells. J. Alloys Compd. 2018, 736, 87-92. [CrossRef]

17. Rosales-Gallegos, I.; Ávila-Niño, J.A.; Hérnandez-Arriaga, D.; Reyes-Reyes, M.; López-Sandoval, R. Flexible rewritable organic memory devices using nitrogen-doped CNTs/PEDOT: PSS composites. Org. Electron. 2017, 45, 159-168. [CrossRef]

18. Jiang, C.; Huang, X.; Sun, B.; Li, Y.; Gao, M.; Ye, L.; Ade, H.; Forrest, S.R.; Fan, J. A 3D nonfullerene electron acceptor with a 9,9'-bicarbazole backbone for high-efficiency organic solar cells. Org. Electron. 2020, 84, 105784. [CrossRef]

19. Fernandes, S.S.M.; Raposo, M.M.M.; Mesquita, I.; Andrade, L.; Mendes, A.; Justino, L.L.G.; Burrows, H.D. Synthesis and characterization of push-pull bithiophene and thieno[3,2-b]thiophene derivatives bearing an ethyne linker as sensitizers for dye-sensitized solar cells. Org. Electron. 2017, 49, 194-205. [CrossRef]

20. Wang, P.H.; Lee, H.F.; Huang, Y.C.; Jung, Y.J.; Gong, F.L.; Huang, W.Y. The proton dissociation constant of additive effect on self-assembly of poly(3-hexyl-thiophene) for organic solar cells. Electron. Mater. Lett. 2014, 10, 767-773. [CrossRef]

21. Wang, L.; Hu, M.; Zhang, Y.; Yuan, Z.; Hu, Y.; Zhao, X.; Chen, Y. Single-strand and ladder-type polymeric acceptors based on regioisomerically-pure perylene diimides towards all-polymer solar cells. Polymer 2019, 162, 108-115. [CrossRef]

22. Feng, L.; Xu, X.; Guo, X. Comparative Analysis of Organic Thin Film Transistor Structures for Flexible E-Paper and AMOLED Displays. In ECS Transactions; ECS: Bristol, UK, 2011; Volume 37, pp. 105-112.

23. Wang, Z.; He, M.; Chen, B.; Hu, B. Azo-linked porous organic polymers/polydimethylsiloxane coated stir bar for extraction of benzotriazole ultraviolet absorbers from environmental water and soil samples followed by high performance liquid chromatography-diode array detection. J. Chromatogr. A 2020, 1616, 460793. [CrossRef]

24. Li, F.; Chen, W.; Yuan, K.; Chen, Y. Photovoltaic performance enhancement in P3HT/ZnO hybrid bulk-heterojunction solar cells induced by semiconducting liquid crystal ligands. Org. Electron. 2012, 13, 2757-2762. [CrossRef]

25. Xu, X.; Sun, L.; Shen, K.; Zhang, S. Organic and hybrid organic-inorganic flexible optoelectronics: Recent advances and perspectives. Synth. Met. 2019, 256, 116137. [CrossRef] 
26. An, Q.; Zhang, F.; Sun, Q.; Zhang, M.; Zhang, J.; Tang, W.; Yin, X.; Deng, Z. Efficient organic ternary solar cells with the third component as energy acceptor. Nano Energy 2016, 26, 180-191. [CrossRef]

27. Kwong, C.Y.; Djurišić, A.B.; Choy, W.C.H.; Li, D.; Xie, M.H.; Chan, W.K.; Cheah, K.W.; Lai, P.T.; Chui, P.C. Efficiency and stability of different tris(8-hydroxyquinoline) aluminium (Alq3) derivatives in OLED applications. Mater. Sci. Eng. B Solid-State Mater. Adv. Technol. 2005, 116, 75-81. [CrossRef]

28. Xiao, P.; Dong, T.; Xie, J.; Luo, D.; Yuan, J.; Liu, B. Emergence of White Organic Light-Emitting Diodes Based on Thermally Activated Delayed Fluorescence. Appl. Sci. 2018, 8, 299. [CrossRef]

29. Ciric-Marjanovic, G. Recent advances in polyaniline research: Polymerization mechanisms, structural aspects, properties and applications. Synth. Met. 2013, 177, 1-47. [CrossRef]

30. Khanna, V.K. Displays and light-emission devices. In Flexible Electronics; Institute of Physics Publishing: Bristol, UK, 2019; Volume 3, pp. 1-62. ISBN 978-0-7503-2456-4.

31. Mekheimer, R.A.; Ahmed, E.A.; Sadek, K.U. Recent developments in the chemistry of pyrazolo[4,3-c]quinolines. Tetrahedron 2012, 68, 1637-1667. [CrossRef]

32. Wainwright, M.; Kristiansen, J.E. Quinoline and cyanine dyes-Putative anti-MRSA drugs. Int. J. Antimicrob. Agents 2003, 22, 479-486. [CrossRef]

33. Stephens, D.E.; Larionov, O.V. Recent advances in the C-H-functionalization of the distal positions in pyridines and quinolines. Tetrahedron 2015, 71, 8683-8716. [CrossRef]

34. Elie, M.; Renaud, J.L.; Gaillard, S. N-Heterocyclic carbene transition metal complexes in light emitting devices. Polyhedron 2018, 140, 158-168. [CrossRef]

35. Hung, L.S.; Chen, C.H. Recent progress of molecular organic electroluminescent materials and devices. Mater. Sci. Eng. R Rep. 2002, 39, 143-222. [CrossRef]

36. Li, A.; Luo, C.; Liu, Y.; Li, L.; Lin, Y.; Liu, K.; Zhou, C. Zn-promoted H $\beta$ zeolite for gas-phase catalyzed aza-heterocyclic-aromatization of acrolein dimethyl acetal and aniline to quinolines. Mol. Catal. 2020, 486, 110833. [CrossRef]

37. Alemi Tameh, F.; Safaei-Ghomi, J. Synthesis of spiro[pyrazoloquinoline-oxindoles] and spiro[chromenopyrazolooxindoles] promoted by guanidine-functionalized magnetic $\mathrm{Fe}_{3} \mathrm{O}_{4}$ nanoparticles. J. Iran. Chem. Soc. 2018, 15, 1633-1637. [CrossRef]

38. Gu, Z.; Guo, J.; Hao, R.; Lin, Z.; Qian, Y.; Ma, C.; Fan, Y.; Deng, X.; Zhang, G.; Peng, W.; et al. An efficient strategy to supervise absorption, mobility, morphology of photovoltaic molecule by inserting a D-A unit. Dye. Pigment. 2019, 166, 515-522. [CrossRef]

39. Matuszek, M.; Filapek, M.; Gancarz, P.; Krompiec, S.; Grzegorz Małecki, J.; Kotowicz, S.; Siwy, M.; Maćkowski, S.; Chrobok, A.; Schab-Balcerzak, E.; et al. Synthesis and photophysical properties of new perylene bisimide derivatives for application as emitting materials in OLEDs. Dye. Pigment. 2018, 159, 590-599. [CrossRef]

40. Ulahannan, R.T.; Panicker, C.Y.; Varghese, H.T.; Musiol, R.; Jampilek, J.; Alsenoy, C.V.; War, J.A.; Manojkumar, T.K. Vibrational spectroscopic studies and molecular docking study of 2-[(E)-2-phenylethenyl]quinoline-5-carboxylic acid. Spectrochim. Acta Part A Mol. Biomol. Spectrosc. 2015, 150, 190-199. [CrossRef] [PubMed]

41. Szlachcic, P.; Uchacz, T. Influence of fluorine on the photophysical, electrochemical properties and basicity of 1,3-diphenylpyrazolo[3,4-b]quinoline derivatives. J. Lumin. 2018, 194, 579-587. [CrossRef]

42. Rechthaler, K.; Rotkiewicz, K.; Danel, A.; Tomasik, P.; Khatchatryan, K.; Köhler, G. Emissive Properties and Intramolecular Charge Transfer of Pyrazoloquinoline Derivatives. J. Fluoresc. 1997, 7, 301-309. [CrossRef]

43. Hu, Y.Q.; Gao, C.; Zhang, S.; Xu, L.; Xu, Z.; Feng, L.S.; Wu, X.; Zhao, F. Quinoline hybrids and their antiplasmodial and antimalarial activities. Eur. J. Med. Chem. 2017, 139, 22-47. [CrossRef]

44. Chen, N.; Zhang, C.; Dong, X.; Liu, Y.; Sun, Y. Activation and stabilization of lipase by grafting copolymer of hydrophobic and zwitterionic monomers onto the enzyme. Biochem. Eng. J. 2020, 158, 107557. [CrossRef]

45. Ghate, M.; Dahule, H.K.; Kalyani, N.T.; Dhoble, S.J. Deep blue light emitting Cyno-DPQ phosphor with large stokes shift and high thermal stability for OLEDs and display applications. Optik 2017, 149, 198-205. [CrossRef]

46. Luszczynska, B.; Dobruchowska, E.; Glowacki, I.; Danel, A.; Ulanski, J. Thermoluminescence of the blue light-emitting system based on poly(9-vinylcarbazole) doped with a pyrazoloquinoline dye. J. Lumin. 2009, 129, 1215-1218. [CrossRef] 
47. Hosseinnezhad, M.; Rouhani, S.; Gharanjig, K. Extraction and application of natural pigments for fabrication of green dye-sensitized solar cells. Opto-Electron. Rev. 2018, 26, 165-171. [CrossRef]

48. Iwan, A.; Boharewicz, B.; Parafiniuk, K.; Tazbir, I.; Gorecki, L.; Sikora, A.; Filapek, M.; Schab-Balcerzak, E. New air-stable aromatic polyazomethines with triphenylamine or phenylenevinylene moieties towards photovoltaic application. Synth. Met. 2014, 195, 341-349. [CrossRef]

49. Iwan, A. Thermotropic and opto(electrical) properties of liquid crystalline imine with two fluorinated chains. J. Mol. Liq. 2010, 157, 67-72. [CrossRef]

50. Kirsch, P. Modern Fluoroorganic Chemistry: Synthesis, Reactivity, Applications; Wiley Blackwell: Hoboken, NJ, USA, 2005; ISBN 9783527603930.

51. Tao, Y.T.; Balasubramaniam, E.; Danel, A.; Jarosz, B.; Tomasik, P. Sharp green electroluminescence from 1H-pyrazolo[3,4-b]quinoline-based light-emitting diodes. Appl. Phys. Lett. 2000, 77, 1575-1577. [CrossRef]

52. Andersson, T.G.; Andreasson, M.; Klement, U.; Lee, C.B.; Pujilaksono, B.; Uddin, A. Preparation and characterization of the ITO surface and the Al/Alq3/ITO heterostructure for OLEDs. Mater. Sci. Eng. B Solid-State Mater. Adv. Technol. 2007, 145, 48-56. [CrossRef]

53. Nalwa, H.S.; Rohwer, L.S. Handbook of Luminescence, Display Materials, and Devices; American Scientific Publishers: Valencia, CA, USA, 2003; ISBN 9781588830104.

54. Liu, B.; Altintas, Y.; Wang, L.; Shendre, S.; Sharma, M.; Sun, H.; Mutlugun, E.; Demir, H.V. Light-Emitting Diodes: Record High External Quantum Efficiency of 19.2\% Achieved in Light-Emitting Diodes of Colloidal Quantum Wells Enabled by Hot-Injection Shell Growth. Adv. Mater. 2020, 32, 2070054. [CrossRef]

Publisher's Note: MDPI stays neutral with regard to jurisdictional claims in published maps and institutional affiliations. 